\title{
Enzyme Histochemical Study of the Motor Nerve Cells in Axonal Reaction
}

\author{
By \\ Itaru Watanabe \\ From the Second Department of Surgery (Director: $M$. Ka sai) and \\ the Department of Pathology (Director: K. Akazaki), Tohoku. \\ University School of Medicine, Sendai
}

(Received for publication, April 2, 1965)

\begin{abstract}
Axonal reaction of the motor nerve cells in the anterior horn of rabbit spinal cord was induced operatively. On the chromatolytic cells, enzyme histochemical stainings were performed at the respective dates after operation. Light microscopical observations on these cells with the comparison of the normal cells in symmetrical anterior horn, demonstrated prominent increases of TPN-, DPN- diaphorase, G6P dehydrogenase and acid phosphatase activities, moderate increases of both glutamic and lactic dehydrogenase, accompanied with decreases of cytochrome oxidase, succinic dehydrogenase, non-specific esterase and thiamine pyrophosphatase activities.

Some presumptions were made from the findings, considering the previous biochemical and electron microscopical results, on these cells under axonal reaction; 1. the heterogeneous distributions of enzyme activities among mitochondria and among lysosomes according to their functional states, 2. the activated metabolism via the pentose monophosphate shunt, and 3 . the lysosomal differentiation into mitochondria.
\end{abstract}

Chromatolysis following axonal section has been well confirmed by numerous investigators ${ }^{1,2}$ since Nissl's original observation. Many results have been obtained morphologically and biochemically, at the cytoscale, to elucidate its pathophysiological significance. A high concentration of RNA, protein and lipids has been estimated quantitatively in the stimulated or regenerating nerve cells under chromatolysis, ${ }^{3-5}$ and moreover the alterations or the multiplication of intracytoplasmic organellae have been observed thereby eleetron microscopically. 6-14 However the clarification of intracytoplasmic metabolism in these cells still remains unsatisfactory and the cytochemical findings are further expected.

Recent advances of enzyme histochemistry have brought some reliable staining methods and suggest that the local activity of an enzyme could be indicative of a metabolism along the pathway which contains that particular enzyme. In 
addition, after the application of differential centrifugation technique, ${ }^{\mathbf{1 5}, \mathbf{1 6}}$ the staining of local enzyme activity has become available as a marker of intracytoplasmic organella.

This experiment was aimed to observe the changes of enzyme activities of chromatolytic motor nerve cells in the anterior horn of rabbit spinal cord, in which the retrograde axonal reaction was induced operatively. Observation upon the enzyme activities of the nerve cells in simply induced chromatolytic state, with reasonable staining controls of normal cells in symmetrical anterior horn, may allow to discuss some possible metabolic conditions of nerve cells in these states.

\section{MATERIALS AND METHODS}

Rabbits of both sexes weighing $2.5-3.0 \mathrm{~kg}$ were used. One side of the brachial plexus was simply dissected by cervical approach, after the procedures of Barron and Tuncbay, ${ }^{17}$ under nembutal anesthesia. On the $1,3,5,7,11,15,20$, $30,40,60,80$ and 90 th day postoperatively, the cervical enlargement of spinal cord was removed out carefully. Material was taken from the segments $\mathrm{C}_{6}, \mathrm{C}_{2}$ and $\mathrm{C}_{8}$ containing both sides, which were treated immediately for the enzyme histochemical staining procedures. In different individuals the experiments in the same conditions were carried out 3-4 times repeatedly.

One horizontal half of the material was immersed into the Baker's formolcalcium, ${ }^{18}$ which was added with sucrose in $7.5 \%$, after Holt. ${ }^{19}$ Fixation was continued for $18-20$ hours at $2-4^{\circ} \mathrm{C}$ and ordinary frozen sections in $20 \mu$ thickness were made. Another piece of the material, which was directly adjacent to the former one, was kept in hexan of $-60^{\circ} \mathrm{C}$ to make the cryostat sections. On these sections the following enzyme activities were stained out with respective methods. Original workers, incubation time and temperature, and the abbreviations of each enzyme kind are as the followings:

1) Acid phosphatase

$$
\text { : Ac-ph. (pH 4.8) (Gomori })^{20} \ldots 60-80 \mathrm{~min} \text { at } 37^{\circ} \mathrm{C}^{*}
$$

2) Thiamine pyrophosphatase

: TPP-ase (Novikoff) ${ }^{21} \ldots 50-60 \mathrm{~min}$ at $37^{\circ} \mathrm{C}^{*}$

3) Cytochrome oxidase

: Cyt. oxid. (Burstone) $)^{22}$. . . 30-40 min at room temp.

4) Succinic dehydrogenase

: SDH (Seligman) $)^{23} \ldots 60-90 \mathrm{~min}$ at $37^{\circ} \mathrm{C}$

5) TPN diaphorase

: TPND (Cohen) $)^{24} \ldots 30 \mathrm{~min}$ at $37^{\circ} \mathrm{C}$

6) G6P dehydrogenase

: G6PDH (Cohen) $)^{24} \ldots 30 \mathrm{~min}$ at $37^{\circ} \mathrm{C}$

7) DPN diaphorase

$$
\text { : DPND (Cohen) }{ }^{24} \ldots 15-20 \mathrm{~min} \text { at } 37^{\circ} \mathrm{C}
$$


8) Lactic dehydrogenase

$$
\text { (Novikoff) })^{25} \ldots 50-60 \mathrm{~min} \text { at } 37^{\circ} \mathrm{C}^{*}
$$

: LDH (Nachlas) ${ }^{26,27} \ldots 15-20$ min at $37^{\circ} \mathrm{C}$

(Novikoff) ${ }^{25} \ldots 50-60$ min at $37^{\circ} \mathrm{C}^{*}$

9) Glutamic dehydrogenase

$$
\text { : DGH }(\text { Nachlas })^{26,27} \ldots 15 \mathrm{~min} \text { at } 37^{\circ} \mathrm{C}
$$

10) Non-specific naphthol AS esterase

: Esterase (Gomori) ${ }^{20} \ldots$ 15-20 min at room temp.*

* Fixation was made before incubation.

After the completion of the staining for each enzyme activity, the sections were mounted in $50 \%$ aqueous solution of PVP or glycerin jelly. The conventional Nissl staining with $0.1 \%$ cresylecht violet or $0.1 \%$ thionine was performed on the adjacent paraffin sections. Observations were made light microscopically on the ventro-lateral motor nerve cells in anterior horn at the respective dates after operation. In the present study all the results were based on a comparison between the motor nerve cells in the anterior horn of the operated side and those in another side from the same section. The enzyme stainings were, as a rule, rather faintly made in order to visualize the comparative intensity of the staining results.

\section{OBSERVATIONS}

As already described in many works, the motor nerve cells under axonal reaction represented typical chromatolysis for many weeks. From the 3-5th day after peripheral dissection, the motor nerve cells began to swell and in the perinuclear area the Nissl substances began to break up. As time went on, within 9 days, the swelling increased, the cell body lost any angularity it had, the Nissl substances underwent a progressive peripheral disintegration and the nucleus, sometimes with the nucleus cap, was displaced to the periphery of the cell. This morphological state continued to the date $30-40$ th postoperatively, and then the reproduction of the Nissl substances progressed with increasing basophility in the reformed cytoplasm.

In these chromatolytic cells, some became atrophic from the early days of peripheral dissection and disappeared without showing any sign of regeneration, and some disappeared after showing regenerating responses for a few weeks or more. On the terminal stage: from the 60 th to the 90 th postoperative day, there appeared some heavily basophilic motor nerve cells among the outstanding gliosis in the anterior horn on the operated side.

\section{Acid phosphatase}

Early increase of this enzyme activity in these cells was already pointed out by Bodian, Mellors and others, ${ }^{28,29}$ and recently by Barron and Tuncbay. ${ }^{17}$ 
Approximately the same results were obtained in this study. The activity was recognized as fine granules of equal size, suspectedly identical to the lysosomes. 16,30,31 The intracytoplasmic elevation of the activity in chromatolytic cells began as early as the 2nd day of the axon section, and represented itself as not only the increase in number of the enzyme-active granules but the increase in their staining intensity. They were not restricted to the chromatolytic region as was described previously, but were distributed homogeneously as far as into the long stretches of dendrites.

The most intense staining at the 7-9th day moderated gradually to the normal range until the 40th day,

$\mathrm{NaF}\left(0.01 \mathrm{M}\right.$ )in staining media had totally inhibited this enzyme activity. ${ }^{20}$ No nuclear staining appeared in this staining condition.

\section{Thiamine pyrophosphatase}

Golgi-networks in nerve cells and microglias were impregnated distinctly by virtue of the characteristic staining property of this enzyme. ${ }^{21}$ The progressive alterations of the Golgi-network, as were described as "retispersion" and "retisolution", ${ }^{32}$ were observed in nerve cells under the axonal reaction. These changes principally went in parallel with the chromatolysis and the reconstruction of the network was not performed until the reproduction of the Nissl substances was completed. The changes of this apparatus were observed, namely, to be rather similar to the description of Penfield. ${ }^{32}$ As to the staining intensity of cytoplasm, a relative decrease was noticed in chromatolytic cells. $\mathrm{NaF}(0.01 \mathrm{M})$ in staining media displayed no effect on the enzyme activity. ${ }^{21}$

\section{Cytochrome oxidase}

In normal cells the activity was recognized as tiny round particles in equal size, which were stained in dark brown and distributed homogeneously in the cytoplasm. Nucleus, nucleolus, axon hillock and marginal region were free from the granules. These granules were assumed as mitochondria from their distribution and the enzyme activity, which was totally inhibited with $0.01 \mathrm{M} \mathrm{KCN}$ in the staining solution. The diffuse back staining which appeared in light brown after prolonged incubation was decided to be staining artefact, though it was also susceptible to $\mathrm{KCN}$ treatment.

The decrease of the enzyme activity was only remarkable after the chromatolysis was completed: from the 11-15th day after operation. The decrease in the number of the enzyme-active granules, that of the mitochondria, progressed in the swelling nerve cells from the peripheral part of cell bodies until the granules could be scarcely counted over the remaining diffuse back staining within 20 days. This staining condition lasted for 40 days thereafter, and in the reformed basophilic cells the enzyme activity returned to normal or slightly elevated states. 
The enzyme activity of myelin sheaths which were stained out around the motor nerve cells in the anterior horn was also decreased on the operated side. Gräff's method ${ }^{33}$ was performed without success to detect the alteration of the enzyme activity on the mitochondria in this experiment.

\section{Succinic dehydrogenase}

The enzyme activity was disadvantageously strong in the surrounding tissue in the rabbit spinal cord. Mitochondria were recognized as densely stained granules in the nerve cell, which were intermingled with the cytoplasmic coloration. With $0.025 \mathrm{M}$ malonic acid in the staining media, the stainings above mentioned were totally suppressed. ${ }^{24}$

The decrease of the activity began antecedent to that of cytochrome oxidase, from the 7-9th day, and continued to about the 60th day. Relatively coarse granules which were arranged along the cell membrane, suspectedly to be enzyme activity of synapses, disappeared before the fine diformazan precipitates in swelling cell body lost their coloration. The activities in the surrounding tissues remained unchanged. In small and condensed cells, which might be going into atrophy in the early stage, relatively high activity was noticed.

The bulging or the cluster formation of mitochondria which has been stated previously as denaturating manner ${ }^{34,35}$ of these organellae, was not seen in these cells as far as it concerned with the staining results of these two respiratory enzymes.

\section{TPN diaphorase}

In normal motor nerve cells the enzyme activity was almost undistinguishable from the surrounding tissues, which were faintly stained in diffuse reddish color of monoformazan, and was free from diformazan precipitates. Whereas in the chromatolytic cells the enzyme activity began to increase from the 5-7th day, as intracytoplasmic blue diformazan precipitations, which were distributed diffusely in the cytoplasm and appeared in granules too fine to be recognized as mitochondria. In the early stage of chromatolysis there occasionally marked intracytoplasmic blue staining in laminary pattern as if there stained the Nissl substances that were just breaking up.

From the 10th to the 40th day an accelerative elevation of the enzyme activity was recognized as the increased number of activity granules and as the increased diffuse staining of back ground. ${ }^{36}$ These were the most striking changes of the enzyme activities so far investigated. In the most intensely stained cells the diffuse diformazan precipitates invaded even into the nuclei and dendrites. In the cells found in the latest stage the blue coloration of diformazan still remained.

The enzyme activities were also marked in the actively proliferating glial 
cells ${ }^{37,38}$ in the operated anterior horn. Presumable synaptic activities, which were occasionally seen in the marginal zone of the cells, ${ }^{39}$ became not to be found, although the cytoplasmic activity was elevated.

\section{G6P dehydrogenase}

The prominent elevation of this enzyme activity, second to that of TPND, was observed simultaneously with that of TPN diaphorase, and until the 60th day the promoted diffuse staining of the swollen cytoplasm was continued without any granular deposition of diformazan. Dendrites were not stained out in these staining condition. The nucleus was almost covered by the intensity of the intracytoplasmic diformazan precipitation.

\section{DPN diaphorase}

The enzyme activity in normal nerve cells was much stronger in diffuse staining of cytoplasm than in distinct forms of granules, except in the case of fixed section where the soluble component ${ }^{40,41}$ of the enzyme was seen preferably inhibited.

The elevation of the enzyme activity progressed in most cases from the 9 11th day, with 4-5 days of delay from that of TPND activity. Until the 40th day the activity kept elevated in the chromatolytic cells, but it was not so prominent as was seen in that of TPND. The granular diformazan deposits, which were suspected as mitochondrial activities ${ }^{42}$ in chromatolytic cells and were concentrated in the center of cell body, increased in their number and each color density. Diffuse back staining by extramitochondrial cell component, where the main part of DPND is proposed to exist in, ${ }^{40,41}$ was also promoted while diffuse staining of dendrites became longer and heavier.

The nucleus was almost covered with heavy diformazan deposits, and the cell body figured as if it recovered its angularity because of the prominent staining of dendrites.

Glial cells in the anterior horn on the operated side showed the enzyme activities; microglias in their nuclei and oligodendroglias in their cytoplasm, especially when they were actively proliferating, as were demonstrated in TPND staining. The coarse granules at synaptic region lost their enzyme activity in the chromatolytic cells.

\section{Lactic dehydrogenase}

Simultaneously with the elevation of DPND activity, relative increase of both $\mathrm{LDH}$ and GDH activity was observed in the chromatolytic cells. LDH activity appeared in the longly stretched cell processes as well as in the swollen cell body, and the peripheral part of the cytoplasm was in some occasions impregnanted heavier than the center of cell body.

Glial cells were stained out as the same manner in DPND staining. Atrophic 
or degenerating cells also showed strong activities of this enzyme.

The survival of both DPND and LDH in formalin fixation ${ }^{26}$ was confirmed, though it needed relatively longer incubation to get the same staining intensity as in non-fixed section. No essential difference was seen against the non-fixed section, except that the soluble component of DPND was seen more easily suppressed than mitochondrial one.

\section{Glutamic dehydrogenase}

Moderately promoted diformazan precipitation in chromatolytic cells was characterized by its irregular distribution in the cytoplasm while the normal cells showed almost homogeneous staining of monoformazan. It was cloud-like occasionally, and as in the case of LDH staining, the cell periphery was seen impregnated rather heavier and laminary at sites.

No mitochondrial impregnation was successful. ${ }^{43}$

\section{Non-specific esterase}

From the 5-7th day the activity granules, which were in normal state scattered diffusely in cell body and processes with relative condensation in the perinuclear region and to the cell membrane, lost their contour and became too fine to be recognized as granules. The decrease of the activity revealed itself as homogeneous orange coloration of cytoplasm. This decreasing process was prominent in the cells of the 15-30th day which were already swollen and chromatolytic.

During the 60-90th day there found no cells on the process of losing its activity in the treated anterior horn, but some large cells with processes appeared, which stained diffusely in deep red.

\section{DISCUSSION}

Spatz ${ }^{1}$ and Hartmann $(1947)^{44}$ pointed out that in the regenerating nerve cells the number of mitochondria multiplied about 2 folds under the observation with basic fuchsin staining. Hartmann (1954), ${ }^{9}$ Hudson and Hartmann (9161), ${ }^{11,13}$ and Porter and Bowers (1963) ${ }^{14}$ have recently confirmed the fact electron microscopically. In this observation, on contrary to these reports, the mitochondria which were stained out by virute of their cytochrome oxidase and SDH activities diminished their number in chromatolytic cells under axonal section. Howe and Mellors (1945) ${ }^{45}$ had formerly described, in accord with this result, a decrease of cytochrome oxidase activity quantitatively in their biochemical assay of spinal cord gray matter containing motor nerve cells subjected to peripheral dissection.

On the other hand, when the staining of DPN-diaphorase activity was performed in these cells, a considerable increase of this enzyme activity was observed throughout the cytoplasm, both in the multiplying mitochondria and in the 
diffuse back staining.

These facts bring in an assumption that there exists different function in these mitochondria multiplying at the center of regenerating nerve cells, from that of the mitochondria in the normal ones. Provided that the metabolic level of these cells is not lowered, ${ }^{3}$ the multiplied mitochondria in this state are assumed to work preferably in some other functional role to aerobic respiration. The increased activities of intracytoplasmic lactic dehydrogenase, furthermore, suggest the elevated glycolytic metabolism in cytoplasm of these cells. For the mitochondria in the very same cell, too, it may be allowed to make an assumption to functionate in the glycolytic pathway, which has been recently discovered in the mitochondria of nerve cell. ${ }^{46-49}$ The outstanding DPND activity of them in chromatolytic cells is beyond understanding.

The diffuse appearance of GDH activity in the cytoplasm is contradictory to the fact that the enzyme mainly exists in the mitochondria, after differential centrifugation assay. ${ }^{43}$ We have no base to reason about the finding, neither.

The intracytoplasmic constituents of the regenerating nerve cells had been already detected quantitatively by Brattgard and others ${ }^{3-4}$ in the hypoglossal nucleus, and they noticed that the chromatolytic nerve cells produced $2-3$ folds of RNA, proteins and lipids in their swelling cytoplasm. These cells, in the cases of this enzyme histochemical observations, showed prominent elevation of G6P-DH and TPN-D activities and the elevated state of these enzyme activities retained for a relatively longer period. It seems reasonable to suspect from their biochemical characteristics that these enzymes may be required for the active synthesis of lipids and RNA.

With the consideration of the decrease of respiratory enzymes in these cells as noted before, the elevation of G6P-DH and TPN-D activities may reflect the activated intracytoplasmic metabolism via the pentose monophosphate pathway for the consequent production of these substances. For the evidence, 6phosphogluconic acid dehydrogenase activity involved in this metabolic pathway should be confirmed another time.

By the way, TPND (or DPND) was, in this study, as TPN-H (DPN-H) tetrazolium reductase, interpreted to include not only the TPN (DPN) specific flavoprotein enzyme but any substance or pathway which was able to oxidize TPN-H (DPN-H) and transport $\mathrm{H}^{+}$to tetrazolium. Moreover in this study, the so-called endogenous dehydrogenase activity 50,51 should be ruled out from the staining results, which were obtained by the use of Tetrazolium as $\mathrm{H}^{+}$acceptor. Incubation of control sections in a solution composed of the tetrazolium with or without coenzyme (DPN or TPN) yielded no formazan precipitations, except a weak monoformazan formation by extremely longer incubation. Subsequently, in order to exclude that "enzyme" activity, the $\mathrm{pH}$ of the staining solution was adjusted to neutral since its optimal $\mathrm{pH}$ is said to be in the higher alkaline range, ${ }^{20}$ 
and the incubation time was planned to be as short as possible.

In regard to the activity of non-specific esterase in normal cells, the granular appearance may be understood as lysosomal activity ${ }^{52}$ provided that the major part of soluble or microsomal esterases had to be inhibited by formalin fixation. $\mathbf{5 2 , 5 3}$ In chromatolytic cells the esterase-active granules diminished their numbers whereas the acid phosphatase-active granules still increased in their number at that time. These findings are relating that the lysosomes with esterase activity have diminished their number or/and their enzyme activity and that the multiplying lysosomes are not provided with esterase activity. To explain these divergent results on lysosomal enzyme activities, the author could not help presuming the heterogeneous distribution of enzymes among lysosomes.

On the diffuse, intense activities of non-specific esterase in the cells which appeared in the latest stage, there is only way to see them to have such intense microsomal esterases that they escape from the formalin inhibition. The increase of microsomal esterase activity may be connected with the increased basophility of cytoplasm in this stage, since the cytoplasmic basophility of a cell has been interpreted as that of microsomes. ${ }^{6,8}$

The previous descriptions about the increase of acid phosphatase activity in chromatolytic nerve cells ${ }^{28.29}$ might be based on the still not improved staining technique which may have caused some differences in details between recent articles. These changes of this enzyme activity as well as those of Golgi apparatus represented by TPPase activity, provided evidences for the axonal reaction of each cells under these operative procedure, besides the morphological changes in the Nissl staining.

The prominent elevation of acid phosphatase activity or the increase in number of lysosomes in the early stage of chromatolysis and their recoveries to normal range may reflect a passibility of their involvement in the multiplication of mitochondria in these cells. To confirm this opinion, Rouiller and Bernhard $(1956)^{54}$ had pointed out, at first, the transitional process of microbodies to mitochondria in regenerating liver, and Hudson and Hartmann (1961) ${ }^{11}$ that of dense bodies to mitochondria in neurons under axonal section electron microscopically with some subsidiary works..$^{9,13}$ In their papers it was noticed that, among the various forms of dense bodies, there found some highly organized dense bodies which possessed electron transparent area with either one or two dense layers and were very similar in appearance to mitochondria. Counts made on micrographs by them also proved an associated increase in the number of dense bodies to that of mitochondria. The lysosomal differentiation into mitochondria, at least in the case of nerve cells in axonal reaction, is very suggestive after these reports, in spite of the recent finding of "cytolysome" by Novikoff and others, ${ }^{55-57}$ that is rejecting this opinion.

The survived motor nerve cells at the latest stage of axonal reaction were 
found very rarely on the operated side. Beside the increased basophility in the Nissl staining, these cells were seen to have recovered their enzyme activities in Ac-ph. TPPase, GD. and G6P-DH, and remained elevated in Cyt. oxid., SDH, EST, TPND and DPND. The survived cells in the damaged anterior horn suggest that the outgrowing axons, until this stage, may reach to the end-plastes and the cells may recover their nervous function to have the higher activities of some enzymes. Thus they must be compensating for the disappeared cells in the inactive atrophy with or without abortive outgrowth of axon.

Some presumptions were made on the enzyme histochemical results observed in the motor nerve cells in an operatively induced chromatolytic state. Biochemical assumptions will be still under debates, though contradictory considerations were avoided as possible. It is to be regretted that the accompanied stainings have been spared for many other kinds of enzymes demonstrable histochemically today. Many findings, the reasons for which are not clearly understood at present, have remained not fully interpreted. A detailed critical analysis of these findings is naturally restricted after light microscopical observation and would go beyond the limits of this paper. Further investigations will be required, since the electron microscopical demonstrations of intracytoplasmic localization of some enzyme activities are in progress as recently reported by others. ${ }^{19,58-60}$

\section{References}

1) Scholz, W. Handbuch d. spez. path. Anat. u. Histologie, XII/I, 117. ed by HenkeLubarsch, Berlin, 1957.

2) Hydén, H. The Cell, IV/5, 215, ed. by J. Brachet, London, 1960.

3) Brattgard, S.O., Edström, J.E. \& Hydèn, H. Exp. Cell Res, 1958, Suppl. 5, 185.

4) Edström, J.E. \& Hydèn, H. J. Neurochem., 1959, 5, 43.

5) Fisher, J. \& Lodin, Z. Nature, 1958, 181, 341.

6) Palay, S.L. \& Palade, G.E. J.B.B.C., 1955, 1, 69.

7) Luse, S.A. ibid., 1956, 2, 530.

8) Ruizin, L. \& Dmochowski, L. J. Neuropath. exp. Neurol., 1956, 15, 12.

9) Hartmann, J.F. Anat. Rec., 1954, 118, 19.

10) Causey, G. \& Hoffman, H. Brit. J. Cancer, 1955, 9, 666.

11) Hudson, G. \& Hartmann, J.F. Z. Zellforsch., 1961, 54, 147.

12) Smith, K.R. Jr. J. comp. Neurol., I961, 116, 103.

13) Hudson, G., Lazarow, A. \& Hartmann, J.F. Exp. Cell. Res., 1961, 24, 440.

14) Porter, K.R. \& Bowers, M.B. J.B.B.C., 1963, 19, No. 135 of ASCB 3rd Ann. Meeting.

15) Schneider, W.C. \& Hogeboom, G.H. Cancer Res., 1951, 11, 1.

16) deDuve, C. \& Pressman, B.C. Biochem. J., 1955, 60, 604.

17) Barron, K.D. \& Tuncbay, T.O. Amer. J. Path., 1962, 40, 637.

18) Bakrer, J.R. Quart. J. micr. Sci., 1946, 87, 441.

19) Holt, S.J. \& Hicks, R.M. J.B.B.C., 1961, $11,31$.

20) Pearse, A.G. Histochemistry, London, 1960.

21) Novikoff, A.B. \& Goldfisher, S. Proc. nat. Acad. Sci., 1961, 47, 802.

22) Burstone, M.S. J. Histochem. Cytochem., 1960, 8, 63.

23) Seligman, A.M. Science, 1951, 113, 317. 
24) Cohen, R.B. Proc. Soc. exp. Biol., 1959, 101, 405.

25) Novikoff, A.B. \& Masek, B. J. Histochem. Cytochem., 1958, 6, 217.

26) Nachlas, M.M., Walker, D.G. \& Seligman, A.M. J.B.B.C., 1958, 4, 29.

27) Farber, E., Dunlop, C.E. \& Sternberg, W.H. J. Histochem. Cytochem., 1956, 4, 254.

28) Bodian, D. \& Mellors, R.C. Proc. Soc. exp. Biol., 1943, 55, 243.

29) Bodian, D. \& Mellors, R.C. J. exp. Med., 1945, 81, 459.

30) Becker, N.H. \& Barron, K.D. Amer. J. Path., 1961, 38, 161.

31) Becker. N.H., Goldfisher, S. \& Novikoff, A.B. J.B.B.C., 1960, 8, 649.

32) Penfield, W.G. Brain, 1920, 43, 290.

33) Gräff, S. Zbl. Path., 1922, 32, 337.

34) Avers, C.J. \& Tkal, M.M. J. Histochem. Cytochem., 1963, 11, 157.

35) Becker. N.H. Amer. J. Path., 1961, 38, 587.

36) Nachlas, M.M. \& Seligman, A.M. J.B.B.C.,1958, 4, 467.

37) Rubinstein, L.J., Klatzo, I. \& Miquel, J. J. Neuropath. exp. Neurol., 1962, 21, 116.

38) Schiffer, D. J. Histochem. Cytochem., 1963, 11, 335.

39) Palay, S.L. J.B.B.C., 1956, Suppl. 2, 193.

40) Hogeboom. G.H. J. biol Chem., 1949, 177, 847.

41) Schneider, W.C. \& Hogeboom. G.H. ibid., 1956, 222, 967.

42) Novikoff, A.B. J.B.B.C., 1961, 9, 47.

43) Cascarano, J. \& Zweifach, B.W. ibid., 1959, 5, 309.

44) Hartmann, J.F. Anat. Rec., 1947, 97, 390.

45) Howe, E.W. \& Mellors, R.C. J. exp. Med., 1945, 81, 489.

46) Hesselbach, M.L. \& deBuy, H.G. Proc. Soc. exp. Biol., 1953, 83, 62.

47) Barazas, R. \& Lagnado, J.R. J. Neurochem., 1959, 5, 1.

48) Abood, L.G. \& Brungraber, E. J. biol. Chem., 1959, 234, 1307.

49) Stahl, W.L. \& Beattle, D.S. J.B.B.C., 1963, 19, 293.

50) Hopkins, F.G. \& Dixon, M. J. biol. Chem., 1922, 54, 527.

51) Racker, E. Physiol. Rev., 1955, 35, 1.

52) Shnitka, T.K. \& Seligman, A.M. J. Histochem. Cytochem., 1961, 9, 504.

53) Wachstein, M. \& Meisel, E. ibid., 1961, 9, 325.

54) Rouiller, M.D. \& Bernhard, W. J.B.B.C., 1956, Suppl. 2, 355.

55) Novikoff, A.B. \& Essner, E. ibid., 1962, 15, 140.

56) Napolitans, L. ibid., 1963, 18, 478.

57) Ashford, Th. P. \& Porter, K.P. ibid., 1962, 12, 198.

58) Sabatin, D.D., Benseh, K.G. \& Barrnett, R.J. J. Cell. Biol., 1963, 17, 19.

59) Sabatini, D.D., Miller, F. \& Barmett, R.J. J. Histochem. Cytochem., 1964, $12,57$.

60) Goldfisher, S., Essner, E. \& Novikoff, A.B. ibid., 1964, 12, 72. 


\section{Legends for Figures}

Fig. 1. Normal motor nerve cells in the anterior horn of rabbit spinal cord. Nissl staining. $\times 200$.

Fig. 2. The postoperative 3rd day. Beginning of central chromatolysis. Nissl staining. $\times 200$.

Fig. 3. Postoperative 9th day. Central chromatolysis, ballooning of cell bodies and eccentric nuclei. Nissl staining. $\times 200$.

Fig. 4. Ac-ph. in the normal. $\times 400$.

Fig. 5. Ac-ph. in the postop. 15th day. Prominent increases of enzyme-active granules. $\times 400$.

Fig. 6. TPPase in the normal. Golgi network is active in enzyme activity. Glial activity $(g) . \quad \times 200$.

Fig. 7. TPPase in the postop. 9th day. Retispersion (rs) and Retisolution ( $\uparrow$ ) are shown. $\times 200$.

Fig. 8. Cyt. oxid. of the normal. Enzyme-active granules are filled in cytoplasms. $\times 200$.

Fig. 9. Cyt, oxid, in the postop. 15th day. Enzyme-active granules are hardly counted and diffuse back stainings remain.

Fig. 10. SDH in the normal. $\times 200$.

Fig. 11. SDH in the postop. 15th day. Prominent decrease of the activity and balloon. ing of cell bodies. $\times 250$.

Fig. 12. TPND in the normal. Cytoplasmic activity is hardly distinguishable from that of the surroundings. $\times 250$.

Fig. 13. TPND in the postop. 6th day. Prominent increase of eytoplasmic activities. Laminary staining like Nissl substances $(\uparrow)$.

Fig. 14. G6PDH in the normal. Diffuse homogeneous staining. $\times 200$.

Fig. 15. G6PDH in the postop. 15th day. Prominent increase of the diffuse enzyme activity. Nuclei are almost convered. $\times 200$.

Fig. 16. DPND in the normal. Granular appearance of the activity is barely remarkable. $\times 200$.

Fig. 17. DPND in the postop. 20th day. Prominent increase of the activity, even into nuclei and dendrites. $\times 200$.

Fig. 18. LDH in the normal. Diffuse homogeneous staining. $\times 200$.

Fig. 19. LDH in the postop. 20th day. Prominent staining of dendrites and atrophic cells. (a). Glial activity (g). × 200 .

Fig. 20. GDH in the normal. No granular staining is remarkable. $\times 250$.

Fig. 21. GDH in the postop. 20th day. Irregular staining of the cytoplasm. Glial activity $(\mathrm{g}) . \times 250$.

Fig. 22. Esterase in the normal. $\times 200$.

Fig. 23. Esterase in the postop. 15th day. Prominent decrease of granular staining. Glial activity $(\mathrm{g}) . \quad \times 200$. 


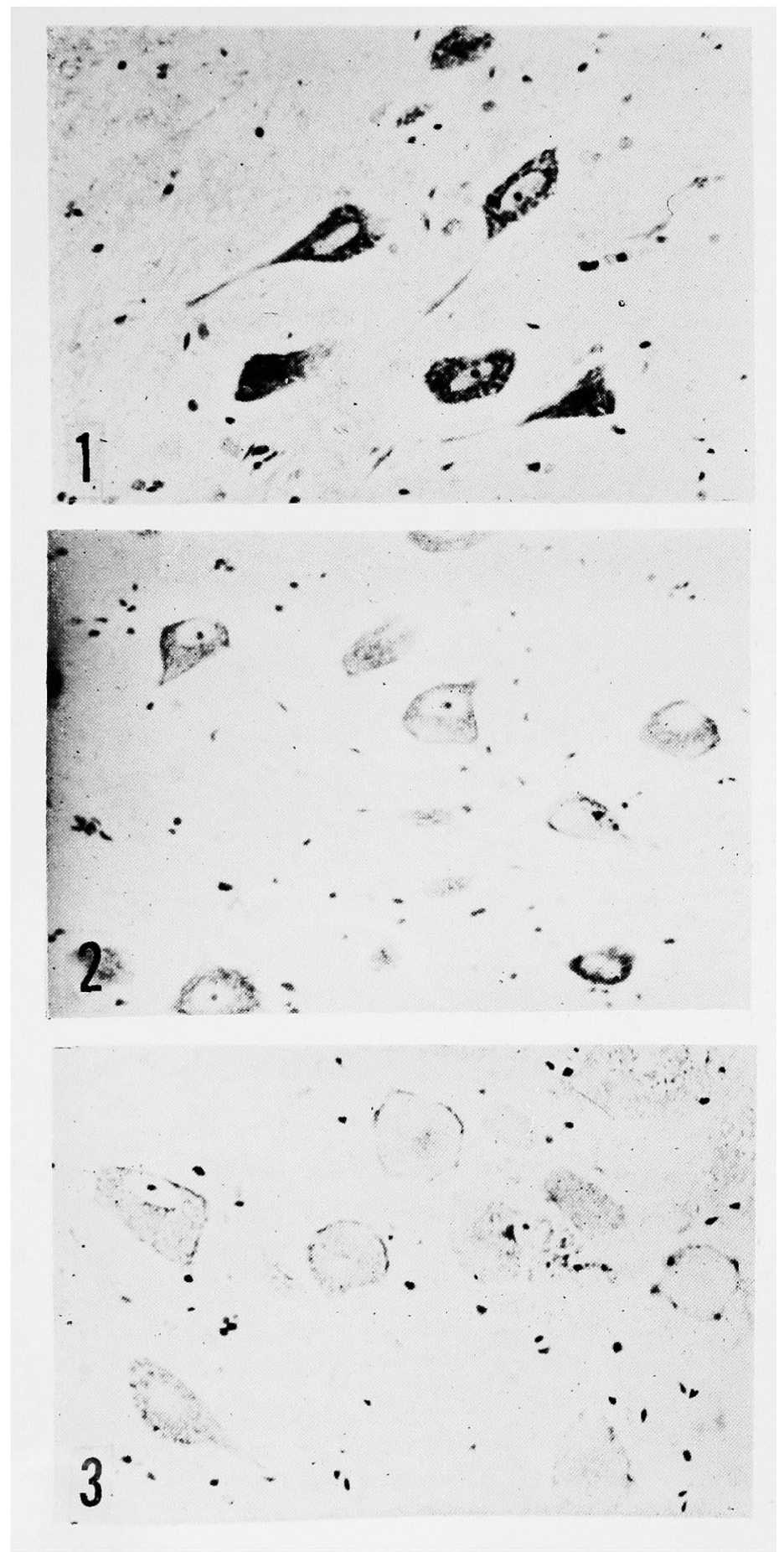




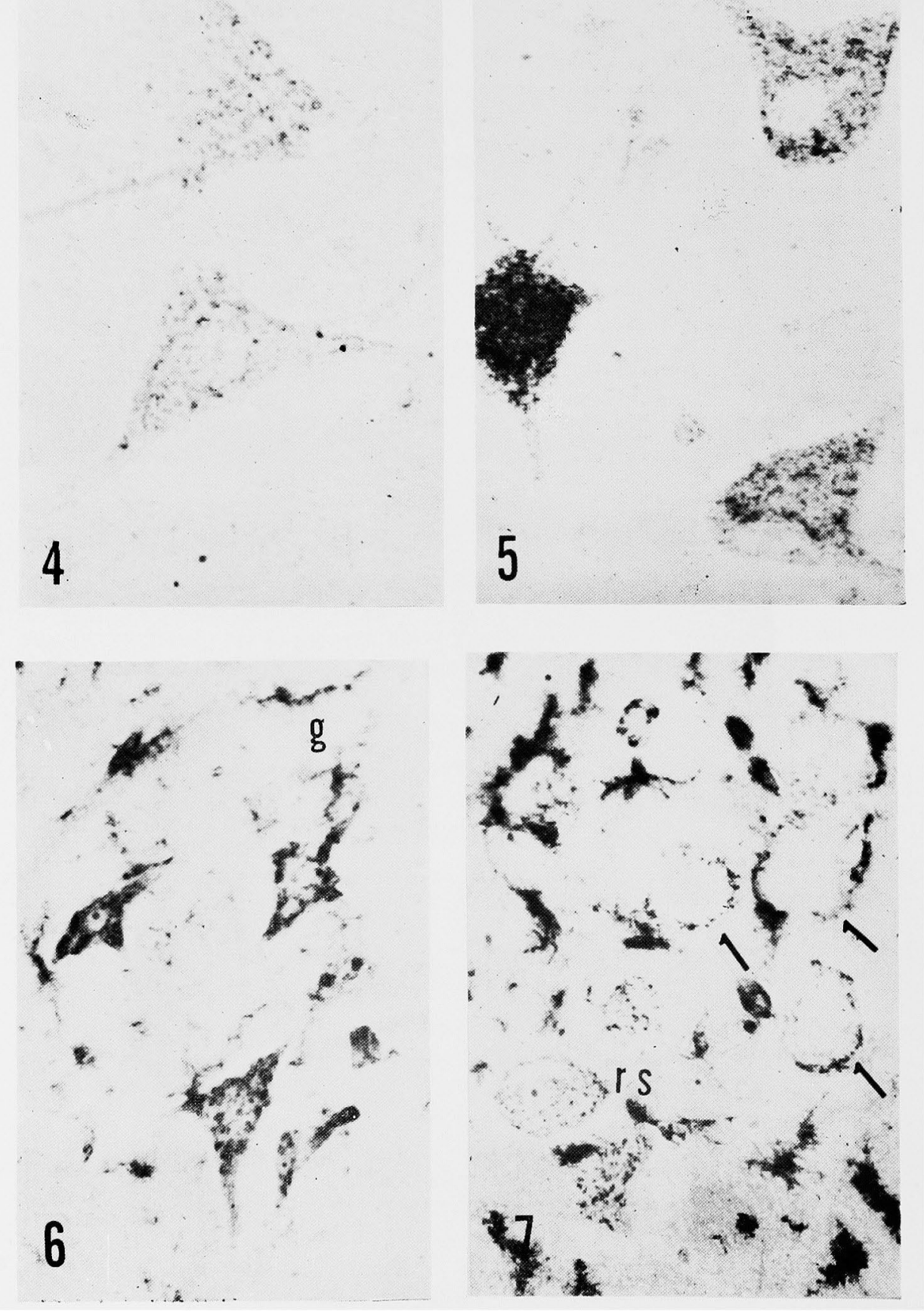




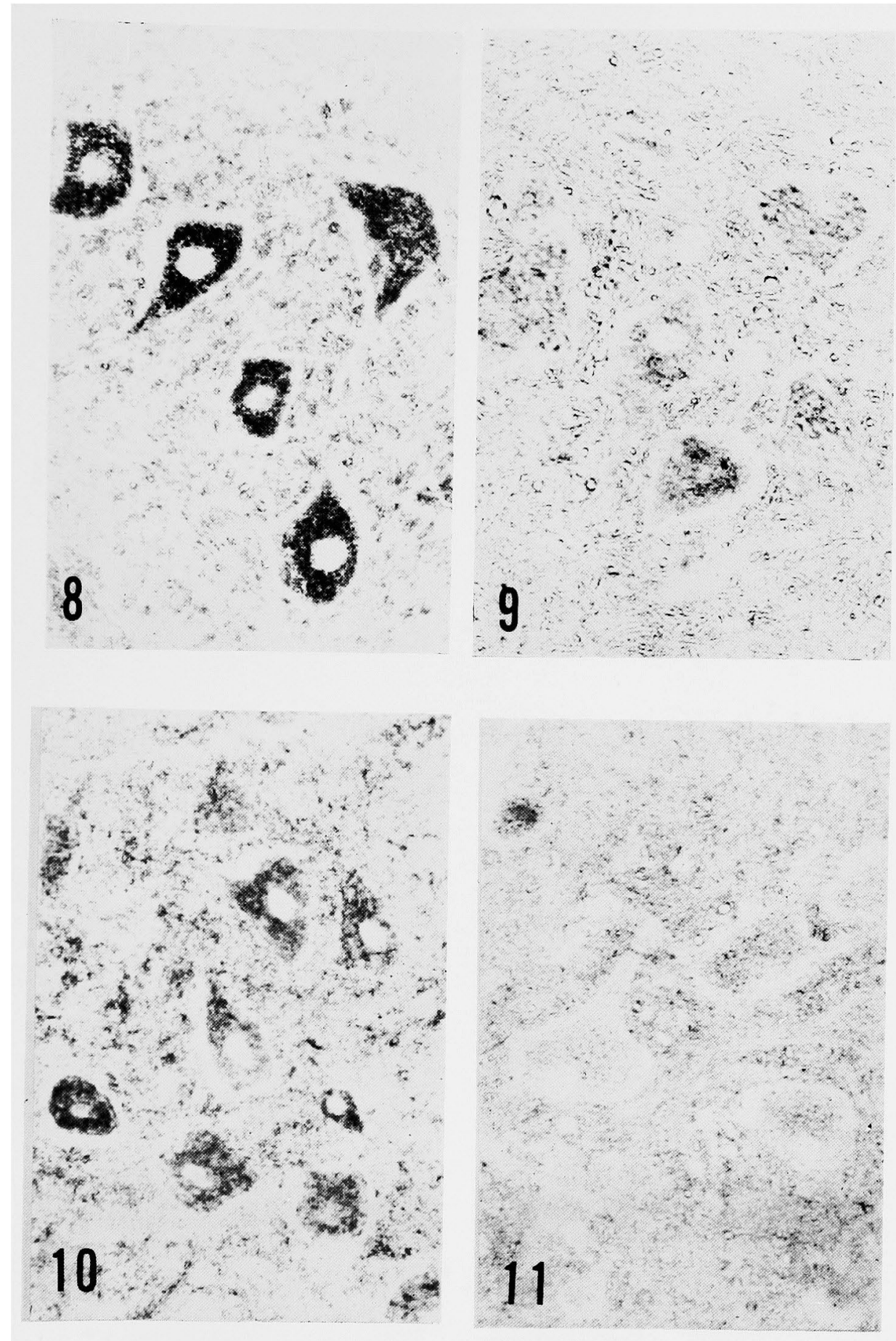



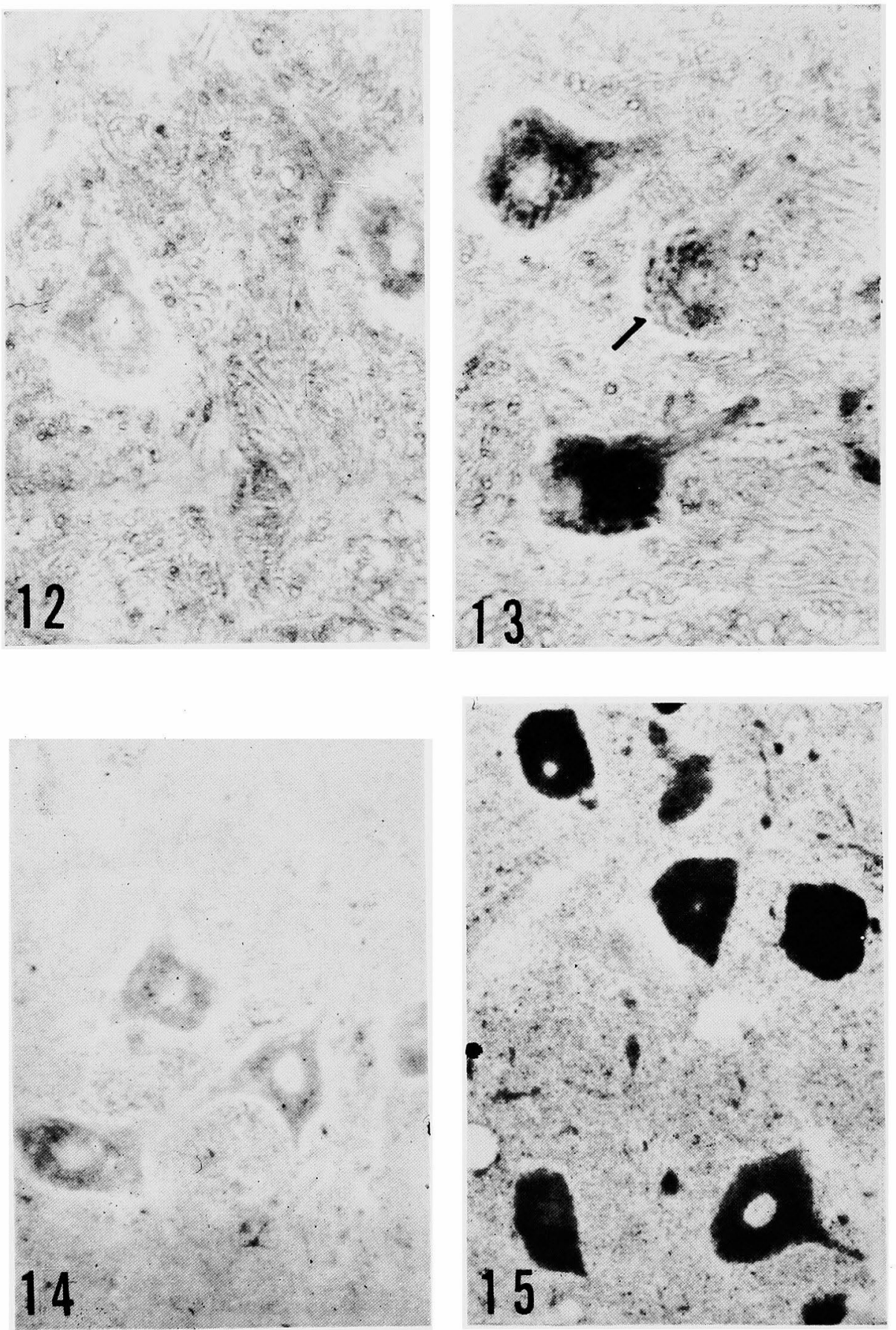

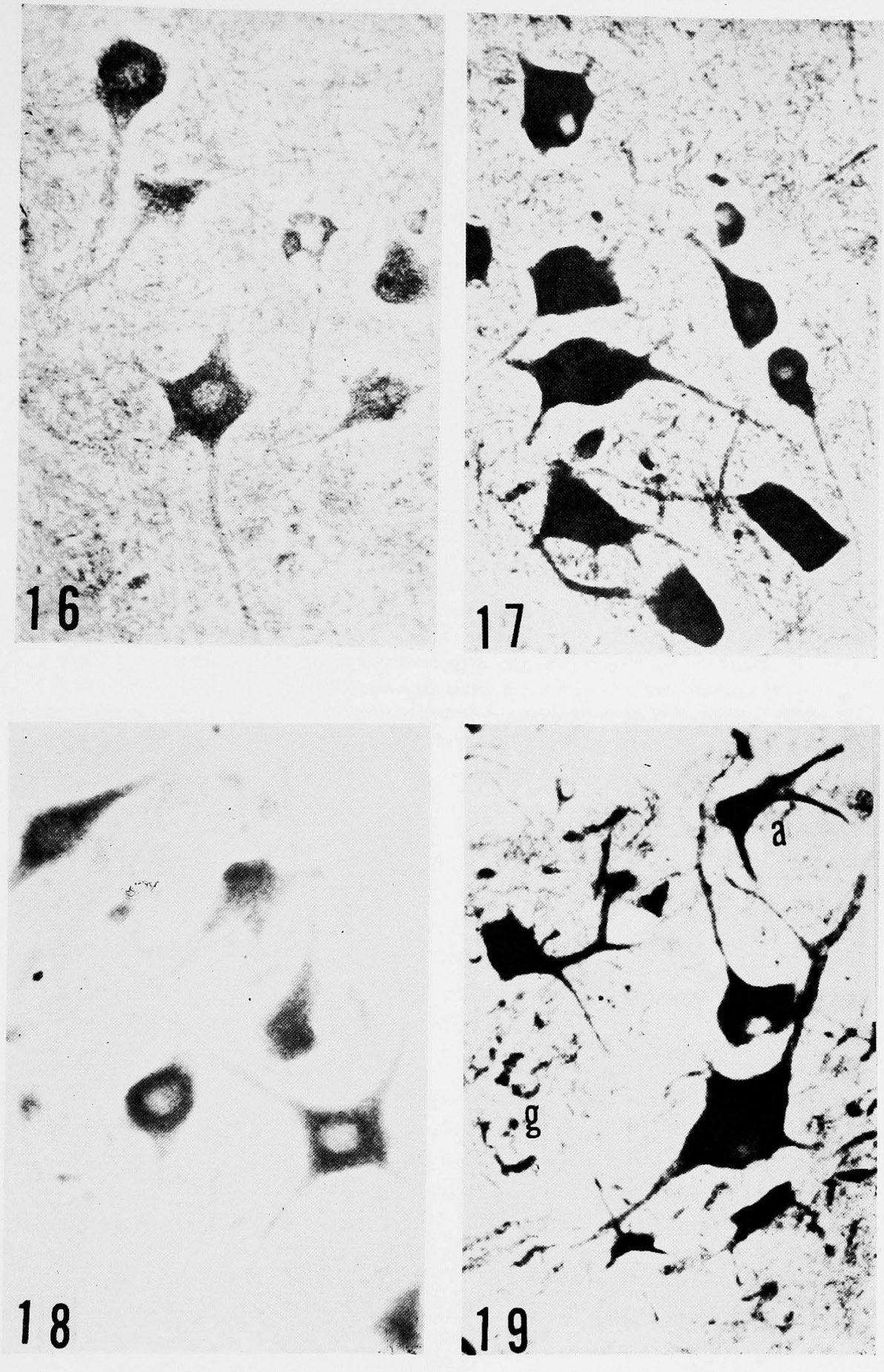
I. Watanabe

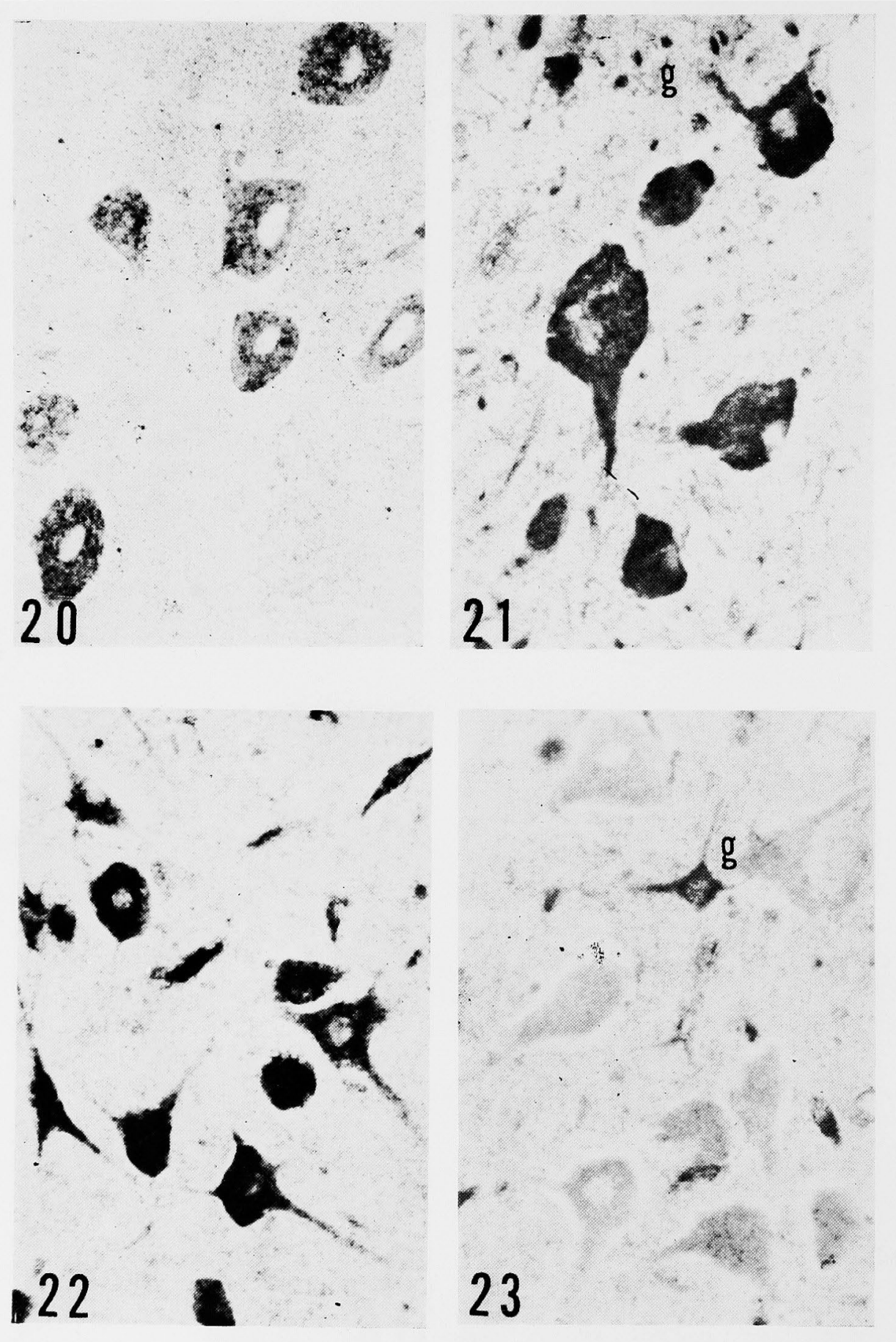

